\title{
Love of Money, Machiavellian, Religiusitas dan Kinerja Auditor
}

\author{
Ida Ayu Chintya Utami Dewi ${ }^{1}$ \\ Fakultas Ekonomi dan Bisnis \\ Universitas Udayana, Indonesia
}

\author{
Gayatri ${ }^{2}$ \\ Fakultas Ekonomi dan Bisnis \\ Universitas Udayana, Indonesia
}

\begin{abstract}
Surel : chintyaidaayu@gmail.com
ABSTRAK

Penelitian ini bertujuan untuk mengetahui pengaruh love of money, machiavellian, religiusitas pada kinerja auditor. Populasi dalam penelitian ini adalah auditor yang bekerja pada Kantor Akuntan Publik di Bali yang terdaftar dalam Direktori Institut Akuntan Publik Indonesia tahun 2019 sehingga didapat sampel sebanyak 109 auditor dengan menggunakan teknik penentuan data sampel jenuh. Teknik analisis data yang digunakan yaitu analisis regresi linier berganda. Hasil penelitian ini menunjukkan bahwa love of money dan machiavellian memiliki pengaruh negatif pada kinerja auditor di Kantor Akuntan Publik di Bali dan religiusitas berpengaruh positif terhadap kinerja auditor di Kantor Akuntan Publik di Bali. Penelitian ini dapat memberikan informasi mengenai love of money, machiavellian, religiusitas pada kinerja auditor Kantor Akuntan Publik di Bali, karena hal tersebut dapat memengaruhi kinerja auditor dalam mencapai hasil kerja yang lebih baik.
\end{abstract}

Kata Kunci: Love Of Money; Machiavellian; Religiusitas.

\section{Love of Money, Machiavellian, Religiosity and Auditor Performance}

\section{ABSTRACT}

This study aims to determine the effect of love of money, machiavellian, religiosity on auditor performance. The population in this study were auditors working at the Public Accountant Firm in Bali which were listed in the Indonesia Public Accountants Institute Directory in 2019 so that a sample of 109 auditors was obtained using the technique of determining saturated sample data. The data analysis technique used is multiple linear regression analysis. The results of this study indicate that love of money and machiavellian have a negative influence on the performance of auditors in public accounting firms in Bali and religiosity has a positive effect on auditor performance in public accounting firms in Bali. This research can provide information about love of money, machiavellian, religiosity on the performance of auditors of Public Accounting Firms in Bali, because it can affect the auditor's performance in achieving better work results.

Keywords: $\quad$ Love Of Money; Machiavellian; Religiosity.

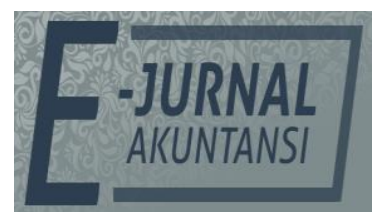

e-ISSN 2302-8556

Vol. 30 No. 12

Denpasar, Desember 2020

Hal. 2999-3009

DOI:

10.24843/EJA.2020.v30.i12.p01

PENGUTIPAN:

Dewi, I.A.C. \& Gayatri (2020). Love of Money,

Machiavellian, Religiusitas dan Kinerja Auditor. E-Jurnal Akuntansi, 30(12), 2999-3009

RIWAYAT ARTIKEL: Artikel Masuk:

2 Maret 2020 Artikel Diterima: 13 Juli 2020

Artikel dapat diakses : https://ojs.unud.ac.id/index.php/Akuntansi/index 


\section{PENDAHULUAN}

Kehidupan bermasyarakat baik antar individu ataupun antar kelompok tentunya memiliki nilai-nilai yang dijadikan dasar dalam kehidupan bermasyarakat. Lingkungan dan budaya masyarakat berpengaruh pada pandangan akan bagaimana cara berperilaku yang dianggap baik. Perilaku yang dianggap baik dan buruk dari masing-masing daerah disebut dengan norma yang nantinya akan diterapkan dalam etika berperilaku. Etika merupakan cara pandang bagaimana menilai sesuatu apakah dikatakan baik ataupun buruk. Etika diperlukan dalam masyarakat guna meminimalisir adanya perselisihan antar masyarakat pada suatu pandangan, karena setiap orang tentunya memiliki pandangannya masing-masing.

Pada Fraud Pentagon Theory, love of money berkaitan dengan tekanan (pressure). Pressure merupakan dorongan orang untuk melakukan tindakan kecurangan (fraud). Tekanan dapat mencakup hampir semua hal temasuk gaya hidup, tuntunan ekonomi, dan lain-lain termasuk dalam hal keuangan maupun non keuangan. Seseorang akan melakukan tindakan kecurangan jika ada dorongan atau motivasi dalam dirinya, salah satu motivasi atau dorongan tersebut adalah kecintaan terhadap uang (Love Of Money).

Pelanggaran etika yang dilakukan oleh seseorang, dapat didasari oleh berbagai faktor, salah satunya adalah berkaitan dengan uang (Arshinta et al., 2007). Uang merupakan salah satu faktor yang mempengaruhi perilaku etis seseorang. Sifat manusia menyebabkan seseorang cenderung selalu memiliki keinginan yang tidak pernah puas dalam suatu pencapaian termasuk keinginan untuk pencapaian finansial (Widiani et al., 2019). Love of money mampu mempengaruhi sifat dari professional akuntan (Sipayung \& Cahyonowati, 2015). Akuntan dengan tingkat love of money yang tinggi umumnya tidak memiliki rasa puas pada pekerjaan serta perilaku etis yang rendah. Pradanti \& Prastiwi (2014) menyatakan seseorang yang memiliki sikap cinta uang berlebih akan cenderung memandang uang sebagai suatu kebutuhan dan berambisi untuk memperolehnya dengan berbagai cara. (Nikara \& Mimba, 2019) menyatakan semakin tinggi hasrat orang memenuhi kebutuhannya dan kecintaannya pada uang, semakin tinggi pula kemungkinan orang tersebut berperilaku tidak etis. Love of money menyebabkan seseorang menjadi tamak dan mengupayakan segala hal untuk mendapatkan uang, meskipun harus mentoleransi tindakan tidak etis. Penelitian yang terkait dengan love of money dan pengaruhnya terhadap persepsi etis mahasiswa akuntansi adalah penelitian oleh Aziz \& Taman (2016) yaitu love of money berpengaruh negatif terhadap persepsi etis mahasiswa akuntansi Universitas Negeri Yogyakarta. Penelitian ini sejalan dengan penelitian Sugiantari \& Widanaputra (2016) yang menunjukkan bahwa love of money berpengaruh negatif pada persepsi mahasiswa akuntansi tentang krisis etika akuntan, akan tetapi penelitian yang dilakukan oleh Rindayanti \& Budiarto, (2017) menyatakan bahwa love of money tidak berpengaruh terhadap perilaku etis mahasiswa akuntansi.

Selain love of money adapun sifat machiavellian dan religiusitas yang berpengaruh pada perilaku seseorang. Machiavellian adalah sifat mengabaikan pentingnya itegritas dan kejujuran dalam mencapai tujuan. Individu ini cenderung tidak produktif (Gkorezis et al., 2015). Sifat Machiavellian pada kinerja 
auditor dapat dijelaskan dengan teori motivasi. Kebutuhan ini berkaitan dengan hasrat untuk memperoleh kekuasaan baik dengan mengontrol orang lain atau meraih tujuan yang lebih besar. Machiavellian dipandang sebagai individu yang manipulatif (Belschak et al., 2015). Individu dengan kebutuhan berkuasa yang tinggi dalam teori motivasi ini digambarkan sebagai individu yang mencari pengakuan dari orang lain, hanya untuk medapat persetujuan. Biasanya kebutuhan akan kekuasaan dapat menyebabkan seseorang perilaku Machiavellian. Apabila dorongan motivasi kebutuhan akan kekuasaan dengan berperilaku Machiavellian terlalu kuat, maka orang itu akan melakukan perbuatan yang curang dan licik demi mendapatkan kekuasaan yang diinginkan dan pastinya akan mempertahankan kekuasaannya. Murphy, (2012) sifat Machiavellian mempunyai kecenderungan untuk mementingkan kepentingan sendiri, manipulatif dan agresif. Saputri \& Wirama (2015) menyatakan sifat machiavellian merupakan sifat negatif karena mengabaikan pentingnya integritas dan kejujuran dalam mencapai tujuan. Mahayani \& Merkusiwati (2016) menjelaskan bahwa sifat Machiavellian merupakan sifat yang negatif karena mengabaikan pentingnya integritas dan kejujuran dalam mencapai tujuan. Gkorezis et al., (2015) Pribadi machiavellian akan bertindak selama hal tersebut mendatangkan keuntungan bagi dirinya. Sifat Machiavellian yang tinggi akan lebih cenderung mengabaikan norma atau peraturan dan menghalalkan segala cara seperti menggunakan taktik manipulatif, melakukan tindakan kecurangan perilaku tidak etis lainnya, demi mendapatkan keuntungan bagi dirinya sendiri.

Religiusitas merupakan tingkat keagamaan seseorang yang cenderung menggambarkan perilaku baik atau buruk. Tingkat religius seseorang tidak berlaku pada perilaku etisnya (Ariyanto, 2020). Seseorang yang memiliki tingkat religiusitas yang tinggi lebih memiliki sikap etis dalam semua aspek kehidupan, yang pada akhirnya membuat mereka kurang bersedia dalam melakukan perilaku yang tidak etis (Hutahahean \& Hasnawati, 2015). Religiusitas pada kinerja auditor dapat dijelaskan dengan teori motivasi dimana salah satu kebutuhan manusia itu adalah kebutuhan afiliasi. Afiliasi merupakan cara seseorang untuk membangun kontak sosial dengan masyarakat guna memenuhi berbagai kebutuhan dan penerimaan dari orang-orang yang di sekitarnya. Kebutuhan ini akan membuat seorang mampu membangun ikatan yang kuat dengan orang lain sehingga bersama-sama mampu menciptakan dampak yang kuat atau powerful.

Berdasarkan teori motivasi tersebut, untuk mencapai apa yang menjadi tujuan diperlukan keinginan atau motivasi pada uang diperkecil pada individu. Love of money sangat berkaitan dengan sifat tamak dan rakus. Ariyanto, (2020) mengartikan love of money sebagai sikap seseorang yang mencitai uang. Seseorang dengan love of money yang tinggi cenderung memiliki kecintaan berlebihan pada uang dan akan menilai segala seseuatu dengan uang (Pemayun \& Budiasih, 2018). Individu dengan love of money yang tinggi akan memperioritaskan uang dalam aspek kehidupannya.

Semakin tinggi tingkat love of money yang dmiliki seseorang, maka akan semakin rendah persepsi etis yang dimilikinya, begitu pula sebaliknya semakin tinggi hasrat orang memenuhi kebutuhannya dan kecintaannya pada uang, semakin tinggi pula kemungkinan orang tersebut berperilaku tidak etis. Desakan 
dalam memenuhi kebutuhan akan membuat seseorang berperilaku tidak etis dalam melakukan pekerjaannya. Terdapat beberapa hasil penelitian yang mengukur pengaruh love of money. Menurut penelitian yang dilakukan Aziz \& Taman (2016) yang meneliti pengaruh love of money dan Machiavellian terhadap persepsi etis mahasiswa akuntansi menyatakan love of money dengan persepsi etika mahasiswa mempunyai pengaruh yang negatif. Semakin tinggi tingkat love of money mahasiswi tersebut, maka akan semakin rendah persepsi etis yang dimiliki (Kurniawan, 2018). Penelitian Aziz \& Taman (2016) yaitu love of money berpengaruh negatif terhadap persepsi etis mahasiswa akuntansi Universitas Negeri Yogyakarta dan didukung oleh penelitian yang dilakukan oleh (Sugiantari \& Widanaputra, 2016). Berdasarkan uraian tersebut, maka peneliti merumuskan hipotesis sebagai berikut.

$\mathrm{H}_{1}$ : Semakin tinggi tingkat Love of money maka makin rendah kinerja auditor.

Biasanya kebutuhan akan kekuasaan dapat menyebabkan seseorang berperilaku Machiavellian. Apabila dorongan motivasi kebutuhan akan kekuasaan terlalu kuat, maka orang itu biasa melakukan perbuatan yang curang, licik dan dusta demi mendapatkan kekuasaan dan pasti akan mempertahankan kekuasannya machiavellianisme dapat didefinisikan sebagai strategi perilaku sosial yang melibatkan seseorang untuk memanipulasi orang lain demi keuntungan pribadi dan sering bertentangan dengan kepentingan umum. Perilaku machiavellian, sangat mudah melakukan manipulasi terhadap orang lain dan tidak menghargai adanya individu lain. Seorang akuntan penting dalam memiliki kualitas untuk menjaga integritasnya dan tepatnya keputusan etis yang dapat dibuat.

Penelitian Aziz \& Taman (2016) menyatakan bahwa Machiavellian mempunyai pengaruh negatif pada persepsi mahasiswa. Saputri \& Wirama, (2015) juga menyatakan individu yang memiliki sifat machiavellian akan memiliki persepsi bahwa etika dan tanggung jawab sosial tidaklah penting. Perilaku machiavellian yang tinggi menyebabkan kinerja akuntan semakin rendah. Berdasarkan uraian tersebut, maka peneliti merumuskan hipotesis sebagai berikut.

$\mathrm{H}_{2}$ : Semakin tinggi tingkat Machiavellian maka makin rendah kinerja auditor.

Teori motivasi mengungkapkan bahwa setiap orang tentunya memiliki kebutuhan yang harus dipenuhi, mulai dari kebutuhan dasar hingga kebutuhan lainnya. Dorongan untuk memenuhi kebutuhan tanpa adanya keahlian dan kesempatan membuat seseorang mampu melakukan berbagai cara, sekalipun tidak etis guna mencapai tujuan. Seseorang yang terlihat memiliki religiusitas tinggi tidak selalu menjamin bahwa dirinya sebagai orang baik. Hal ini di buktikan dengan banyak kasus kejahatan yang melibatkan orang religious. Kasus korupsi pengelolaan dana haji oleh Kementrian Agama Republik Indonesia menjadi salah satu bukti bahwa seseorang dengan religiusitas tinggi tidak selalu berbuat etis. Rendahnya pemahaman serta keyakinan akan agama dari dalam diri seseorang menjadi penyebab maraknya kasus yang melibatkan orang religious. Seseorang yang terlihat religius tanpa sepenuhnya mengerti akan ajaran agama dan komitmen dalam mematuhi berbagai aturan yang ada. Terdapat beberapa hasil penelitian terkait dengan hubungan religiusitas dengan kinerja auditor. Penelitian Wati \& Sudibyo (2016) mendapatkan hasil bahwa 
religiusitas berpengaruh positif terhadap persepsi etis mahasiswa. Penelitian Julianto (2013) menyatakan bahwa tingkat religiusitas mahasiswa yang lebih tinggi akan meningkatkan tingkat persepsi persepsi etis mereka. Semakin tinggi tingkat religius seseorang maka semakin tinggi pula tingkat kinerjanya. Religiusitas tentunya akan mempengaruhi kinerja auditor. Berdasarkan yang sudah dijelaskan, dapat diajukan hipotesis.

$\mathrm{H}_{3}$ : Semakin tinggi tingkat Religiusitas maka makin tinggi kinerja auditor.

\section{METODE PENELITIAN}

Penelitian ini dilakukan pada Kantor Akuntan Publik (KAP) di Bali yang terdaftar dalam direktori Institut Akuntan Publik Indonseia (IAPI) tahun 2019. Populasi dalam penelitian ini adalah auditor yang bekerja pada Kantor Akuntan Publik (KAP) di Bali yang terdaftar dalam Direktori Institut Akuntan Publik Indonesia (IAPI) tahun 2019 yang berjumlah 109 Auditor. Metode penentuan sampel yang digunakan dalam penelitian ini adalah metode sampel jenuh, dimana seluruh anggota populasi dijadikan sebagai sampel. Metode ini digunakan karena jumlah yang memungkinkan untuk dilakukan penelitian secara keseluruhan. Responden yang digunakan adalah seluruh auditor yang bekerja di KAP. Metode pengumpulan data dalam penelitian ini adalah metode survei menggunakan teknik kuesioner.

Penelitian ini menggunakan persamaan regresi linier berganda untuk mengetahui apakah variabel independen memengaruhi variabel dependen. Analisis regresi linier berganda (multiple linier regression) digunakan untuk memecahkan rumusan masalah yang ada, yaitu melihat pengaruh diantara dua variabel atau lebih. Adapun model regresi linier berganda dengan persamaan sebagai berikut:

$$
Y=\alpha+\beta_{1} X_{1}+\beta_{2} X_{2}+\beta_{3} X_{3}+\varepsilon
$$

Keterangan:

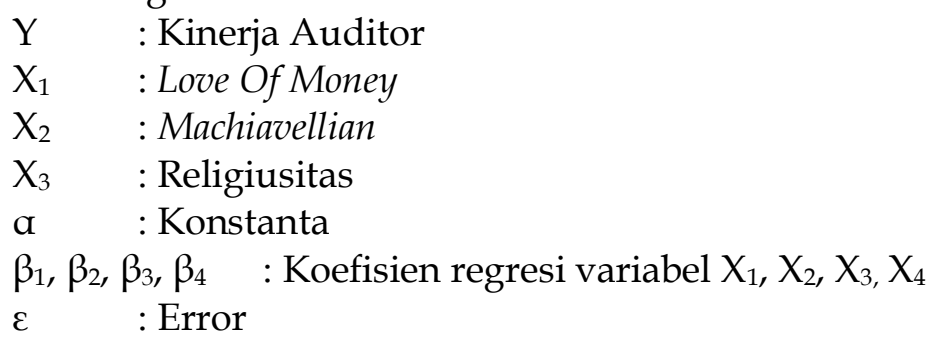

\section{HASIL DAN PEMBAHASAN}

Analisis statistik deskriptif digunakan untuk mengetahui nilai rata-rata, minimal, maksimal dan standar deviasi dari variabel-variabel yang diteliti. Analisis statistik deskriptif menggambarkan secara ringkas data mengenai ukuran pemusatan data, ukuran penyebaran data, serta kecenderungan suatu gugus data. Statistik deskriptif ini akan menyajikan ukuran-ukuran numerik yang sangat penting bagi sampel.

Statistik deskriptif menyajikan informasi mengenai karakteristik variabel yang diteliti. Statistik deskriptif menunjukkan informasi mengenai jumlah pengamatan, nilai minimum, nilai maksimum, nilai mean, dan standar deviasi 
dari masing-masing variabel yang digunakan dalam penelitian, yaitu love of money, machiavellian, religiusitas, dan kinerja auditor. Tabel 1, menjelaskan mengenai hasil uji deskriptif dalam penelitian ini yang menggunakan 49 sampel, seperti berikut.

Tabel 1. Hasil Uji Deskriptif

\begin{tabular}{llllll}
\hline Keterangan & $\mathrm{N}$ & Minimum & Maximum & Mean & Std. Deviation \\
\hline Love of Money & 49 & 14 & 40 & 28.96 & 8.883 \\
Machiavellian & 49 & 33 & 80 & 60.78 & 15.086 \\
Religiusitas & 49 & 30 & 60 & 50.92 & 8.645 \\
Kinerja Auditor & 49 & 9 & 16 & 13.41 & 2.207 \\
Valid N (listwise) & 49 & & & & \\
\hline
\end{tabular}

Sumber: Data Penelitian, 2019

Variabel love of money memiliki nilai minimum sebesar 14 dan nilai maksimum sebesar 40. Nilai standar deviasi variabel love of money sebesar 8.883 yang lebih rendah dibandingkan dengan nilai rata-rata, yang artinya sebaran jawaban responden terkait dengan love of money sudah merata.

Variabel machiavellian memiliki nilai minimum sebesar 33 dan nilai maksimum sebesar 80. Nilai standar deviasi variabel machiavellian sebesar

15.086 yang lebih rendah dibandingkan dengan nilai rata-rata, yang artinya sebaran jawaban responden terkait dengan machiavellian sudah merata.

Variabel religiusitas memiliki nilai minimum sebesar 30 dan nilai maksimum sebesar 60. Nilai standar deviasi variabel religiusitas sebesar 8.645 yang lebih rendah dibandingkan dengan nilai rata-rata, yang artinya sebaran jawaban responden terkait dengan religiusitas sudah merata.

Variabel kinerja auditor memiliki nilai minimum sebesar 9 dan nilai maksimum sebesar 16. Nilai standar deviasi variabel kinerja auditor sebesar2.207 yang lebih rendah dibandingkan dengan nilai rata-rata, yang artinya sebaran jawaban responden terkait dengan kinerja sudah merata.

Analisis regresi berganda merupakan model yang digunakan untuk menganalisis pengaruh lebih dari satu variabel independen terhadap satu variabel dependen. Analisis regresi linier berganda diolah dengan menggunakan software Statistical Package for Social Sciences (SPSS). Hasil analisis regresi linier berganda disajikan pada Tabel 2.

Tabel 2. Hasil Analisis Regresi Linier Berganda

\begin{tabular}{llllll}
\hline Model & \multicolumn{3}{c}{$\begin{array}{c}\text { Unstandardized } \\
\text { Coefficients }\end{array}$} & $\begin{array}{c}\text { Standardize } \\
\text { Coefficients }\end{array}$ & \\
\cline { 2 - 5 } & $B$ & Std. Error & Beta & T & Sig. \\
\hline (Constant) & 14.757 & 1.804 & & 8.178 & 0.000 \\
Love of money & -0.085 & 0.037 & -0.341 & -2.268 & 0.028 \\
Machiavellian & -0.048 & 0.023 & -0.331 & -2.139 & 0.038 \\
Religiusitas & 0.079 & 0.026 & 0.331 & 3.007 & 0.004 \\
R & 0.747 & & & & \\
$R$ Square & 0.558 & & & & \\
Adjusted R Square & 0.529 & & & & \\
F Statistik & 18.973 & & & & \\
Signifikansi Uji F & 0,000 & & & & \\
\hline
\end{tabular}

Sumber: Data Penelitian, 2019

Berdasarkan Tabel 1, dapat disusun persamaan regresi sebagai berikut. 


$$
\mathrm{Y}=14.757-0.085 \mathrm{X}_{1}-0.048 \mathrm{X}_{2}+0.079 \mathrm{X}_{3}
$$

Nilai konstanta sebesar 14.757 menyatakan bahwa apabila variabel love of money $\left(\mathrm{X}_{1}\right)$, machiavellian $\left(\mathrm{X}_{2}\right)$ dan religiusitas $\left(\mathrm{X}_{3}\right)$ sama dengan nol, maka kinerja auditor $(\mathrm{Y})$ adalah sebesar 14.757 satuan.

Nilai koefisien regresi dari love of money $\left(\mathrm{X}_{1}\right)$, sebesar - 0.085 menunjukan bahwa terdapat pengaruh negatif antara variabel love of money terhadap kinerja auditor. Hal ini berarti apabila variabel independen love of money menurun sebesar 1 satuan dengan asumsi bahwa variabel bebas lainnya konstan, maka variabel kinerja auditor akan mengalami penurunan sebesar -0.085 .

Nilai koefisien regresi dari machiavellian $\left(\mathrm{X}_{2}\right)$, sebesar - 0.048 menunjukan bahwa terdapat pengaruh negatif antara variabel machiavellian terhadap kinerja auditor. Hal ini berarti apabila variabel independen machiavellian menurun sebesar 1 satuan dengan asumsi bahwa variabel bebas lainnya konstan, maka variabel kinerja auditor akan mengalami penurunan sebesar -0.048 .

Nilai koefisien regresi dari religiusitas $\left(X_{3}\right)$, sebesar 0.079 menunjukan bahwa terdapat pengaruh positif antara variabel religiusitas terhadap kinerja auditor.

Hal ini berarti apabila variabel independen religiusitas meningkat sebesar 1 satuan dengan asumsi bahwa variabel bebas lainnya konstan, maka variabel kinerja auditor akan mengalami peningkatan sebesar 0.079 .

Koefisien determinasi (R2) digunakan untuk mengetahui dan mengukur kemampuan model dalam menerangkan variasi variabel independen. Berdasarkan Tabel 2, nilai Adjust $R$ Square sebesar 0.529, hal ini berarti 52.9 persen variasi kinerja auditor $(Y)$ dipengaruhi oleh variabel love of money $\left(\mathrm{X}_{1}\right)$, machiavellian $\left(X_{2}\right)$ dan religiusitas $\left(X_{3}\right)$, sisanya sebesar $(100 \%-52.9 \%)=47.1$ persen dipengaruhi oleh faktor lain di luar model.

Berdasarkan hasil analisis regresi pada Tabel 1, variabel independen berpengaruh serempak (simultan) terhadap variabel dependen. Signifikansi F sebesar 0.000 lebih kecil dari 0,05. Hasil uji F yang di analisis dengan

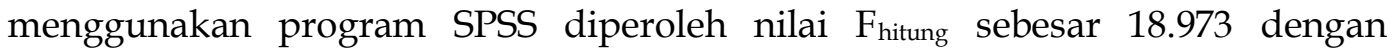
signifkansi sebesar 0,000 < 0,05, maka dapat disimpulkan bahwa pada kelompok yang diuji memiliki perbedaan yang nyata (signifikan). Hasil ini mempunyai arti bahwa ada pengaruh signifikan antara love of money, machiavellian, dan religiusitas terhadap kinerja auditor.

Berdasarkan hasil pengujian (uji t) dalam penelitian ini, didapatkan hasil bahwa love of money mempunyai nilai koefisien regresi negatif -0.085 dan Sig $\mathrm{t}$ $0.028<0,050$. Hasil pengujian tersebut menunjukkan bahwa hipotesis pertama $\left(\mathrm{H}_{1}\right)$ love of money mempunyai pengaruh yang negatif terhadap kinerja auditor pada Kantor Akuntan Publik (KAP) di Bali diterima. Hal ini berarti bahwa apabila seorang auditor memiliki kecintaan terhadap uang berlebihan dan akan menilai segala sesuatu dengan uang maka akan nantinya akan menurunkan kinerja auditor Kantor Akuntan Publik (KAP) di Bali. Berkaitan dengan teori motivasi yang erat kaitannya dengan sifat tamak seseorang akan keinginannya terhadap uang. Uang membuat seseorang mampu memenuhi berbagai kebutuhan dasar dalam teori motivasi. Teori motivasi mengungkapkan bahwa setiap orang tentunya mempunyai kebutuhan yang harus dipenuhi guna memenuhi kebutuhan hidup baik dari kebutuhan dasar hingga kebutuhan yang 
lebih tinggi. Apabila dorongan dirasa kuat, maka motivasi untuk bekerja akan tinggi, apabila dorongan dirasa kuat, maka motivasi untuk bekerja akan tinggi, begitupun sebaliknya. Berdasarkan teori motivasi tersebut, untuk mencapai apa yang menjadi tujuan diperlukan keinginan atau motivasi pada uang diperkecil pada individu. Love of money sangat berkaitan dengan sifat tamak dan rakus. Ariyanto (2020) mengartikan love of money sebagai sikap seseorang yang mencintai uang. Seseorang dengan love of money yang tinggi cenderung memiliki kecintaan berlebihan pada uang dan akan menilai segala seseuatu dengan uang (Pemayun \& Budiasih, 2018). Individu dengan love of money yang tinggi akan memperioritaskan uang dalam aspek kehidupannya, sehingga apabila seorang auditor memiliki love of money yang tinggi maka akan meurunkan kinerjanya.

Hal ini sejalan dengan penelitian sebelumya yang dilakukan oleh Aziz \& Taman (2016) yang meneliti pengaruh love of money dan Machiavellian terhadap persepsi etis mahasiswa akuntansi menyatakan love of money dengan persepsi etika mahasiswa mempunyai pengaruh yang negatif. Semakin tinggi tingkat love of money mahasiswi tersebut, maka akan semakin rendah persepsi etis yang dimiliki (Kurniawan, 2018). Demikian juga penelitian Aziz \& Taman (2016) menemukan love of money berpengaruh negatif terhadap persepsi etis mahasiswa akuntansi Universitas Negeri Yogyakarta dan didukung oleh penelitian yang dilakukan oleh (Sugiantari \& Widanaputra, 2016).

Berdasarkan hasil pengujian (uji t) dalam penelitian ini, didapatkan hasil bahwa machiavellian mempunyai nilai koefisien regresi negatif - 0.048 dan Sig $t$ $0.038<0,050$. Hasil pengujian tersebut menunjukkan bahwa hipotesis kedua $\left(\mathrm{H}_{2}\right)$ machiavellian mempunyai pengaruh yang negatif terhadap kinerja auditor pada Kantor Akuntan Publik (KAP) di Bali diterima. Hal ini berarti bahwa apabila seorang auditor memiliki sifat machiavellian yang tinggi maka akan nantinya akan menurunkan kinerja auditor Kantor Akuntan Publik (KAP) di Bali. Berkaitan dengan teori motivasi sebagai proses yang menjelaskan mengenai kekuatan, arah dan ketekunan seseorang dalam upaya untuk mencapai tujuan (Andjarwati, 2015).

Biasanya kebutuhan akan kekuasaan dapat menyebabkan seseorang berperilaku Machiavellian. Apabila dorongan motivasi kebutuhan akan kekuasaan terlalu kuat, maka orang itu biasa melakukan perbuatan yang curang, licik dan dusta demi mendapatkan kekuasaan dan pasti akan mempertahankan kekuasannya. Machiavellianisme dapat didefinisikan sebagai strategi perilaku sosial yang melibatkan seseorang untuk memanipulasi orang lain demi keuntungan pribadi dan sering bertentangan dengan kepentingan umum. Perilaku machiavellian, sangat mudah melakukan manipulasi terhadap orang lain dan tidak menghargai adanya individu lain (Prabowo \& Widanaputra, 2018). Seorang akuntan penting dalam memiliki kualitas untuk menjaga integritasnya dan tepatnya keputusan etis yang dapat dibuat. Hal ini apabila seorang auditor memiliki perilaku machiavellian yang tinggi maka akan meurunkan kinerjanya

Hal ini sejalan dengan penelitian sebelumnya yang dilakukan oleh Aziz \& Taman (2016) menyatakan bahwa Machiavellian mempunyai pengaruh negatif pada persepsi mahasiswa. Saputri \& Wirama (2015) juga menyatakan individu yang memiliki sifat machiavellian akan memiliki persepsi bahwa etika dan 
tanggung jawab sosial tidaklah penting. Perilaku machiavellian yang tinggi menyebabkan kinerja akuntan semakin rendah.

Berdasarkan hasil pengujian (uji t) dalam penelitian ini, didapatkan hasil bahwa religiusitas mempunyai nilai koefisien regresi positif 0,079 dan Sig t 0.004 $<0,050$. Hasil pengujian tersebut menunjukkan bahwa hipotesis ketiga $\left(\mathrm{H}_{3}\right)$ religiusitas mempunyai pengaruh yang positif terhadap kinerja auditor pada Kantor Akuntan Publik (KAP) di Bali diterima. Hal ini berarti bahwa apabila seorang auditor memiliki religiusitas yang tinggi maka akan nantinya akan meningkatkan kinerja auditor Kantor Akuntan Publik (KAP) di Bali. Berkaitan dengan teori motivasi sebagai proses yang menjelaskan mengenai kekuatan, arah dan ketekunan seseorang dalam upaya untuk mencapai tujuan (Andjarwati, 2015). Dengan adanya sikap religiusitas maka seseorang akan selalu berusaha berperilaku yang baik sesuai dengan ajaran agama yang nantinya akan membuat seseorang selalu bekerja dengan baik sehingga akan meningkatkan kinerjanya. Hal ini karena religiusitas merupakan nilai-nilai agama yang dianut oleh seseorang. Semua agama umumnya memiliki tujuan sama dalam mengontrol perilaku yang baik dan menghambat perilaku buruk (Ariyanto, 2020).

Hal ini sejalan dengan penelitian sebelumya yang dilakukan Wati \& Sudibyo (2016) mendapatkan hasil bahwa religiusitas berpengaruh positif terhadap persepsi etis mahasiswa. Penelitian Julianto (2013) menyatakan bahwa tingkat religiusitas mahasiswa yang lebih tinggi akan meningkatkan tingkat persepsi persepsi etis mereka. Semakin tinggi tingkat religius seseorang maka semakin tinggi pula tingkat kinerjanya. Religiusitas tentunya akan mempengaruhi kinerja auditor.

Penelitian yang dilakukan diharapkan dapat memberikan hasil mengenai analisis faktor - faktor yang mempengaruhi kinerja auditor di Kantor Akuntan Publik (KAP) di Bali. Hasil uji hipotesis dalam penelitian ini ditemukan bahwa secara statistic love of money dan machiavellian memiliki pengaruh negatif pada kinerja auditor di Kantor Akuntan Publik (KAP) di Bali dan religiusitas berpengaruh positif terhadap kinerja auditor di Kantor Akuntan Publik (KAP) di Bali, sehingga hal tersebut sesuai dengan kajian penelitian terdahulu dan sesuai dengan teori. Teori motivasi, dimana teori motivasi terkait kebutuhan manusia untuk meraih atau mendapatkan sesuatu (Pemayun \& Budiasih, 2018). Teori motivasi digunakan untuk menjelaskan hubungan antar variabel dan dapat disimpulkan sebagai alasan seorang untuk menyelesaikan pekerjaannya guna memenuhi berbagai kebutuhan hidup, baik dari kebutuhan dasar hingga kebutuhan yang lebih tinggi. Apabila dorongan dirasa kuat, maka motivasi untuk bekerja akan tinggi, begitupun sebaliknya. Motivasi dapat mempengaruhi hasil kinerja seseorang baik secara positif atau negatif tergantung pada keadaan yang dihadapi oleh orang yang bersangkutan. Penelitian ini dapat memberikan informasi mengenai love of money, machiavellian, religiusitas pada kinerja auditor Kantor Akuntan Publik di Bali, karena hal tersebut dapat memengaruhi kinerja auditor dalam mencapai hasil kerja yang lebih baik.

\section{SIMPULAN}

Love of money berpengaruh negatif dan signifikan terhadap kinerja auditor pada Kantor Akuntan Publik (KAP) di Bali, yakni berarti seorang auditor memiliki 
kecintaan terhadap uang berlebihan dan akan menilai segala sesuatu dengan uang maka kinerja auditor akan menurun. Machiavellian berpengaruh negatif dan signifikan terhadap kinerja auditor pada Kantor Akuntan Publik (KAP) di Bali, yakni berarti seorang auditor memiliki sifat machiavellian yang tinggi maka kinerja auditor akan menurun. Religiusitas berpengaruh positif dan signifikan terhadap kinerja auditor pada Kantor Akuntan Publik (KAP) di Bali, yakni berarti seorang auditor memiliki religiusitas yang tinggi maka kinerja auditor akan meningkat.

\section{REFERENSI}

Andjarwati, T. (2015). Motivasi dari Sudut Pandang Teori Hirarki Kebutuhan Maslow, Teori Dua Faktor Herzberg, Teori xy Mc Gregor, dan Teori Motivasi Prestasi Mc Clelland. Jurnal Ilmu Ekonomi Dan Manajemen, 1(1), 4554. https://doi.org/10.30996/jmm.v2i01.422

Ariyanto, D. (2020). Influence of justice, culture and love of money towards ethical perception on tax evasion with gender as moderating variable. Journal of Money Laundering Control, 23(1), 245-266. https:// doi.org/10.1108/JMLC-06-2019-0047

Arshinta, F., Djasuli, M., \& Yuni Rimawati. (2007). Faktor-Faktor yang Mempengaruhi Persepsi Etika Mahasiswa Akuntansi dengan Love of Money sebagai Variabel Intervening. Jurnal Keuangan Dan Perbankan, 13(2), $128-140$.

Aziz, T. I., \& Taman, A. (2016). PENGARUH LOVE OF MONEY DAN MACHIAVELLIAN TERHADAP PERSEPSI ETIS MAHASISWA AKUNTANSI (Studi Empiris Pada Mahasiswa Akuntansi UNY Angkatan 2013 dan Angkatan 2014). Nominal, Barometer Riset Akuntansi Dan Manajemen, 4(2), 1-14. https:/ / doi.org/10.21831/nominal.v4i2.7998

Belschak, F. D., Den Hartog, D. N., \& Kalshoven, K. (2015). Leading Machiavellians: How to Translate Machiavellians' Selfishness Into ProOrganizational Behavior. Journal of Management, 41(7), 1934-1956. https:// doi.org/10.1177/0149206313484513

Gkorezis, P., Petridou, E., \& Krouklidou, T. (2015). The detrimental effect of machiavellian leadership on employees' emotional exhaustion: Organizational cynicism as a mediator. Europe's Journal of Psychology, 11(4), 619-631. https://doi.org/10.5964/ejop.v11i4.988

Hutahahean, M. U. B., \& Hasnawati, H. (2015). Pengaruh Gender, Religiusitas Dan Prestasi Belajar Terhadap Perilaku Etis Akuntan Masa Depan (Studi Pada Mahasiswa Akuntansi Perguruan Tinggi Swasta Di Wilayah Dki Jakarta). Jurnal Akuntansi Trisakti, 2(1), 49-66. https:// doi.org/10.25105/jat.v2i1.4831

Intan Kusumawathi Nikara, I. A. G., \& Mimba, N. P. S. H. (2019). Pengaruh Love of Money, Machiavellian, Idealisme dan Religiusitas pada Persepsi Etis Mahasiswa Akuntansi. E-Jurnal Akuntansi, 26(1), 536-562. https:// doi.org/10.24843/eja.2019.v26.i01.p20

Julianto, S. (2013). Perception Of Accounting Student: Review Of Gender, Religiosity And The Love Of Money. Jurnal Ilmiah Mahasiswa Feb Universitas Brawijaya, 1(2). 
Kurniawan, I. P. (2018). Pengaruh Love Of Money, Machiavellian, dan Idealisme Pada Persepsi Etis Mahasiswa Akuntansi Fakultas Ekonomi dan Bisnis Universitas Udayana. E-Jurnal Akuntansi Universitas Udayana, 21(3), 2253- 2281. https:/ / doi.org/10.24843/EJA.2018.v23.i01.p20

Mahayani, N., \& Merkusiwati, N. (2016). Pengaruh Persaingan Auditor Dan Sifat Machiavellian Pada Independensi Auditor Dengan Etika Profesi Sebagai Variabel Moderasi. E-Jurnal Akuntansi, 15(2), 1172-1200.

Murphy, P. R. (2012). Attitude, Machiavellianism and the rationalization of misreporting. Accounting, Organizations and Society. https:/ / doi.org/10.1016/j.aos.2012.04.002

Pemayun, A. W., \& Budiasih, I. G. A. N. (2018). Pengaruh Religiusitas, Status Sosial Ekonomi Dan Love Of Money Pada Persepsi Etis Mahasiswa Akuntansi. E-Jurnal Akuntansi, 23(2), 1600-1628. https:// doi.org/10.24843/eja.2018.v23.i02.p30

Prabowo, P. P., \& Widanaputra, A. A. G. P. (2018). Pengaruh Love of Money, Machiavellian, dan Idealisme pada Persepsi Etis Mahasiswa Akuntansi. EJurnal Akuntansi. https:// doi.org/10.24843/eja.2018.v23.i01.p20

Pradanti, N. R., \& Prastiwi, A. (2014). Analisis Pengaruh Love of Money Terhadap Persepsi Etis Mahasiswa Akuntansi. Journal of Accounting, 3(1).

Rindayanti, R., \& Budiarto, D. S. (2017). Hubungan antara Love of Money, Machiavellian dengan Persepsi Etis: Analisis Berdasarkan Perspektif Gender. Akuntabilitas, 10(2), 261-272. https:// doi.org/10.15408/akt.v10i2.6137

Saputri, I. G. A. Y., \& Wirama, D. G. (2015). Pengaruh Sifat Machiavellian Dan Tipe Kepribadian Pada Perilaku Disfungsional Auditor. Jurnal Akuntansi Universitas Udayana, 2(4), 70-86.

Sipayung, E. R., \& Cahyonowati, N. (2015). Analisis Pengaruh Aspek Demografi, Status Sosial Ekonomi Dan Pengalaman Kerja Terhadap Persepsi Etis Mahasiswa Akuntansi Dengan Love Of Money Sebagai Variabel Intervening. Diponegoro Journal of Accounting, 4(2), 1-15.

Sugiantari, N., \& Widanaputra, A. (2016). Pengaruh Idealisme, Relativisme, Dan Love Of Money Pada Persepsi Mahasiswa Akuntansi Tentang Krisis Etika Akuntan. E-Jurnal Akuntansi, 17(3), 2474-2502.

Wati, M., \& Sudibyo, B. (2016). Pengaruh Pendidikan Etika Bisnis Dan Religiusitas Terhadap Persepsi Etis Mahasiswa Akuntansi. Jurnal Economia, 12(2), 183-201. https:// doi.org/10.21831/economia.v12i2.11775

Widiani, N. P., Putri, I. G. A. M. A. D., Sari, M. M. R., \& Wirajaya, I. G. A. (2019). The effect of love of money and emotional intelligence on employee performance with organizational citizenship behavior as mediating variable. International Research Journal of Engineering, IT \& Scientific Research, 5(1), 39-49. https:// doi.org/10.21744/irjeis.v5n1.596 